\title{
A novel copper-binding protein with characteristics of a metallothionein from a clinical isolate of Candida albicans
}

\author{
Ki-Bong Oh, $\uparrow$ Takahide Watanabe and Hideaki Matsuoka
}

Author for correspondence: Hideaki Matsuoka. Tel: +81423 88 7029. Fax: + 81423871503. e-mail: bio-cell@cc.tuat.ac.jp

Department of Biotechnology, Faculty of Technology, Tokyo University of Agriculture and Technology, 2-24-16 Nakamachi, Koganei, Tokyo 184-8588, Japan

\begin{abstract}
It is known that clinical isolates of Candida albicans exhibit a high level of resistance to copper salts, although the molecular basis of this resistance is not clear. To investigate this, a novel copper-binding protein was purified from a clinical isolate of $C$. albicans. The protein was extracted from yeast cells after an induction period of $10 \mathrm{~h}$ in a copper-containing suspension medium. It was further purified by size-exclusion chromatography, ultrafiltration and reversephase HPLC. All protein fractions were analysed for their protein and copper contents. The copper/protein ratio increased steadily throughout the purification process; the most highly purified fraction showed a 210-fold increase compared to the whole-cell extract, with a recovery of $0.03 \%$. The molecular mass of the protein was $10000 \mathrm{Da}$ and a reconstitution study using the purified apoprotein suggested that the equivalent extent of $\mathrm{Cu}(\mathrm{I})$ binding was approximately $14 \mathrm{~mol}$ eq. The amino-terminal segment of the copperbinding protein revealed three Cys-Xaa-Cys motifs, which is typical of a metallothionein (MT), and showed significant homology with mammalian MTs with respect to the positions of the cysteine residues. This is the first report of the isolation of a copper-binding protein from C. albicans.
\end{abstract}

Keywords: Candida albicans, copper-binding protein, protein purification and characterization, amino-terminal sequence, metallothionein

\section{INTRODUCTION}

Copper requirements of micro-organisms are usually satisfied by low external concentrations of the metal (in the order of $1-10 \mu \mathrm{M}$ ), although this is markedly dependent on the copper-complexing capacity of the growth medium. In contrast, copper present at higher levels in its free ionic form $\left(\mathrm{Cu}^{2+}\right)$ can be toxic to microbial cells (Palmiter, 1998; Liu \& Thiele, 1997). Copper toxicity is mainly due to its interactions with nucleic acids (Lippert, 1992), to the alteration of enzyme active sites and to the oxidation of membrane components, processes that may be related to the ability of copper to generate toxic hydroxyl free radicals (Simpson et al., 1988). On the other hand, organically complexed copper is relatively nontoxic to micro-organisms (Maret \& Valle, 1998). To balance the stimulatory and in-

\footnotetext{
†Present address: Natural Products Research Institute, Seoul National University, 28 Yungun-dong, Jongro-ku, Seoul 110-460, Korea.

Abbreviations: $\mathrm{CBB}$, Coomassie brilliant blue; MT, metallothionein; SDTC, sodium diethyldithiocarbamate.
}

hibitory properties of copper, micro-organisms are equipped with a number of homeostatic mechanisms that ensure proper accumulation, distribution and detoxification of the metal. The best understood of these are the metallothioneins (MTs), a family of cysteine-rich polypeptides thought to play a critical role in copper ion storage and detoxification. Fungi invoke a variety of pathways to respond to increased concentrations of metal ions (Cervantes \& Gutierrez-Corona, 1994; Fischer \& Davie, 1998; Liu \& Thiele, 1997; White et al., 1998; Zhu \& Thiele, 1996). Among the sequestration compounds that are induced, MTs and $(\gamma-E C)_{n} G$ peptides constitute the two most widely used detoxification molecules (Mehra \& Winge, 1991; Winge, 1998).

Candida albicans is the most pathogenic and medically important yeast in the genus Candida (Madhani \& Fink, 1998). It has been known for some time that clinical isolates of C. albicans and Candida glabrata exhibit high levels of resistance to both copper and cadmium salts, although the molecular basis of this resistance is not known (Malavasic \& Cihlar, 1992; Mehra \& Winge, 
1991). Recent studies with C. glabrata have revealed that this yeast employs differing mechanisms to detoxify cadmium and copper salts (Liu \& Thiele, 1997). Cadmium salts stimulate the production of $(\gamma-\mathrm{EC})_{n} \mathrm{G}$ peptides, whereas copper salts induce the synthesis of a family of MTs. Several fungi that are pathogenic in humans, including C. albicans, have been screened for the presence of DNA sequences homologous to the Saccharomyces cerevisiae MT gene. Southern blot and restriction enzyme analysis showed that one of the $C$. albicans strains examined by Butt \& Ecker (1987) contained DNA sequences which hybridize with $S$. cerevisiae MT. However, detailed analysis of the putative MT locus of C. albicans has yet to be performed. The cloned MT-like gene could be useful as a selectable marker and for regulated gene expression studies in pathogenic fungi. This paper focuses primarily on the purification of a novel copper-binding protein from a clinical isolate of $C$. albicans. The amino-terminal sequence of the purified protein was determined, and binding of copper was studied.

\section{METHODS}

Yeast strains, medium and culture conditions. C. albicans KULM 83-0300, a clinical isolate, was obtained from the Kitasato University Hospital, Kanagawa, Japan. As a preliminary test of the copper resistance of this isolate, its growth was compared with that of several other yeast strains $(C$. albicans ATCC 10231, Candida tropicalis ATCC 750 and S. cerevisiae IFO 0565$)$ on YPD agar plates $[1 \%(\mathrm{w} / \mathrm{v})$ yeast extract, $2 \%(\mathrm{w} / \mathrm{v})$ polypeptone, $2 \%(\mathrm{w} / \mathrm{v})$ glucose and $2 \%$ $(\mathrm{w} / \mathrm{v})$ agar] containing various concentrations of $\mathrm{CuSO}_{4}$. Growth of the tested yeasts was inhibited at concentrations above $30,15,10$ and $5 \mathrm{mM} \mathrm{CuSO}_{4}$, respectively. The induction of copper-binding protein was detected in all Candida strains by the sodium diethyldithiocarbamate (SDTC) staining method as described below. Thus C. albicans KULM 83-0300 was used throughout this study. To prepare the copperbinding protein, yeast cells $\left(5 \times 10^{6}\right.$ cells $\left.\mathrm{ml}^{-1}\right)$ were grown aerobically in YPD liquid medium at $28{ }^{\circ} \mathrm{C}$. $\mathrm{CuSO}_{4}$ was added to YPD cultures at approximately the midpoint of exponential growth to a final concentration of $5 \mathrm{mM}$. The cells were harvested after $10 \mathrm{~h}$ by centrifugation, washed twice with $\mathrm{H}_{2} \mathrm{O}$ and then lyophilized.

Purification of the copper-binding protein. Samples (10 g) of freeze-dried yeast cells were physically disrupted with a cold mortar and pestle for $20 \mathrm{~min}$. They were then extracted with $100 \mathrm{ml} 20 \mathrm{mM}$ Tris/ $\mathrm{HCl}$ (pH 7.5) buffer containing: $\mathrm{MgCl}_{2} .2 \mathrm{H}_{2} \mathrm{O}, 5 \mathrm{mM}$; KCl, $50 \mathrm{mM}$; glycerol, $5 \%(\mathrm{w} / \mathrm{v})$; PMSF, $1 \mathrm{mM}$; DTT, $3 \mathrm{mM}$; pepstatin A, $1 \mu \mathrm{g} \mathrm{ml} \mathrm{m}^{-1}$; and leupeptin, $0.5 \mu \mathrm{g} \mathrm{ml}{ }^{-1}$. Cell extracts were centrifuged at $28000 \mathrm{~g}$ for $30 \mathrm{~min}$ to obtain a clarified supernatant. The supernatant was concentrated by lyophilization and suspended in $12 \mathrm{ml} \mathrm{N}$-saturated $10 \mathrm{mM}$ Tris/HCl (pH 7.4) containing $0 \cdot 2 \% \quad \beta$-mercaptoethanol and then applied to a column of Sephadex G-75 ( $3 \times 40 \mathrm{~cm}$, Pharmacia Biotech) equilibrated in the same buffer. The copper-binding-protein fractions were identified by copper analysis using atomic absorption spectrophotometry (model AA6600G, Shimadzu). The pooled fractions were concentrated by lyophilization. After resuspension in the same buffer, the sample was ultrafiltered $\left(2000 \mathrm{~g}, 4^{\circ} \mathrm{C}, 20 \mathrm{~h}\right)$ using an Ultrafree- 4 centrifugal filter unit equipped with a high-flux Biomax membrane (nominal molecular-mass cutoff, 30000 Da; Nihon Millipore). The resulting filtrate containing copper-binding protein was applied to a reverse-phase HPLC $\mu$-Bondapak $\mathrm{C}_{18}$ column $(3.9 \times 150 \mathrm{~mm}$; Nihon Waters) connected to a Hewlett Packard HPLC system (HP 1100 series). Adsorbed material was eluted with a linear gradient of $0-10 \%$ solution B $(60 \%$ acetonitrile in solution A) in solution A $(10 \mathrm{mM}$ Tris $/ \mathrm{HCl}$ containing $0 \cdot 2 \% \beta$-mercaptoethanol, $\mathrm{pH} 7 \cdot 4)$ at a flow rate of $1 \mathrm{ml} \mathrm{min}{ }^{-1}$. The major copper-containing peaks were pooled, 4 vols ice-cold acetone were added and the samples incubated overnight at $-80^{\circ} \mathrm{C}$. The precipitate was collected by centrifugation at $28000 \mathrm{~g}$ for $15 \mathrm{~min}$ and stored anaerobically at $-80{ }^{\circ} \mathrm{C}$ with Tris $/ \mathrm{HCl}$ buffer $(\mathrm{pH} 7 \cdot 4)$. This solution was used as purified copper-binding protein for subsequent studies.

PAGE. Nondenaturing PAGE was carried out at $\mathrm{pH} 8.9$ using a $15 \%$ acrylamide gel. Protein was measured by the method of Bradford (1976) using bovine serum albumin as a standard. After completion of electrophoresis, the gel was cut into two strips longitudinally. One strip was used for protein staining with Coomassie brilliant blue (CBB) R-250 as follows. The gel was soaked in $10 \%$ acetic acid containing $0.25 \% \mathrm{CBB}$ and $45 \%$ methanol for $1 \mathrm{~h}$. It was then destained with $10 \%$ acetic acid containing $45 \%$ methanol for $1 \mathrm{~h}$ and stored in $7 \%$ acetic acid containing $5 \%$ methanol. The second strip was used for copper staining with SDTC by incubation with $0 \cdot 2 \%$ SDTC solution overnight (Naiki \& Yamagata, 1976). During incubation, the brown band corresponding to the copperbinding protein appeared against a transparent background.

Molecular mass of the copper-binding protein. The molecular mass of the purified copper-binding protein was measured by HPLC gel filtration on a Shodex Protein KW-802.5 column $(8 \times 300 \mathrm{~mm}$, Showa Denko) at a flow rate of $0.3 \mathrm{ml} \mathrm{min}-1$ with $50 \mathrm{mM}$ Tris/ $\mathrm{HCl}$ containing $0 \cdot 2 \mathrm{M} \mathrm{NaCl}(\mathrm{pH} 7 \cdot 5)$ as an eluent. The molecular mass of the copper-binding protein was measured by comparison with the following calibration standard proteins from the LMW gel filtration calibration kit (Pharmacia Biotech): bovine serum albumin $(67 \mathrm{kDa})$, ovalbumin $(43 \mathrm{kDa})$, chymotrypsinogen $\mathrm{A}(25 \mathrm{kDa})$ and ribonuclease A (13.7 kDa); and insulin chain B (4 kDa, Sigma).

Preparation of apoprotein and amino-terminal sequence analysis. The removal of copper ions from the copper-binding protein was accomplished by boiling the protein with a solution of $10 \mathrm{mM}$ EDTA in $7 \mathrm{M}$ guanidinium hydrochloride containing 0.5 M Tris (pH 8.5) for 5 min (Mehra et al., 1988). The mixture containing apoprotein was filtered with a $0 \cdot 22 \mu \mathrm{m}$ pore-size membrane filter. The resulting filtrate was fractionated by HPLC on a Shodex Protein KW-802.5 column. Adsorbed material was eluted with $0.02 \%$ trifluoroacetic acid. The protein peak was localized by measuring absorbance at $214 \mathrm{~nm}$. The copper-free protein peak was pooled and concentrated by lyophilization. The amino-terminal sequence of the copper-binding protein was determined by automated Edman degradation of carboxymethylated apoprotein (Winge et al., 1985) using a Shimadzu Protein Sequencer PPSQ-10 system (Shimadzu). Cysteine was determined by Edman degradation of $S$-pyridylethylated cysteine residues.

Reconstitution of the apoprotein with $\mathrm{Cu}(\mathrm{I})$. Copper reconstitution was carried out by the addition of increasing mole equivalents of $\mathrm{Cu}(\mathrm{I})$ to the apoprotein. A solution of $\mathrm{Cu}(\mathrm{I})$ prepared by the method of Mehra et al. (1988) was added to apoprotein $(4 \mathrm{nmol})$ dissolved in $0.02 \mathrm{M} \mathrm{HCl}$ to achieve $1-20 \mathrm{~mol}$ eq. copper (mol protein $)^{-1}$. The samples were neutralized with $200 \mu \mathrm{l} 0.2 \mathrm{M}$ dibasic potassium phosphate and diluted to a final volume of $500 \mu \mathrm{l}$ with water. The absorbance and luminescence spectra of the reconstituted 
samples were measured using UV spectrophotometry (model UV-1200, Shimadzu) and spectrofluorometry (model FP-777, Japan Spectroscopic), respectively.

Proton displacement of $\mathrm{Cu}(\mathrm{I})$ from the copper-binding protein. Samples of the native protein $(4 \mathrm{nmol})$ were adjusted to the desired $\mathrm{pH}$ by adding $500 \mu \mathrm{l} 0 \cdot 2 \mathrm{M}$ potassium phosphate preadjusted to that $\mathrm{pH}$. The absorbance spectra of these samples were then recorded. In this experiment, the base line absorbance changed in response to $\mathrm{pH}$ change. A base line correction was performed.

\section{RESULTS}

\section{Induction and isolation of a copper-binding protein from C. albicans}

C. albicans KULM 83-0300 is capable of growth in YPD medium containing high concentrations of copper salts. Inhibition of growth by $50 \%$ requires approximately $15 \mathrm{mM} \mathrm{CuSO}_{4}$. We sought to determine if metalsequestering macromolecules contributed to this apparent copper resistance. A summary of the purification procedure for the copper-binding protein from $C$. albicans KULM 83-0300 is presented in Table 1. Since copper-binding proteins are readily oxidized (Berger et al., 1997), it was necessary to minimize the duration of the purification procedure. In the present work, all purification steps were carried out on two consecutive days with purging using nitrogen. The samples of purified copper-binding protein for subsequent studies were prepared just prior to use. However, the results shown in Table 1 suggested that the copper-binding protein accounts for less than $0 \cdot 1 \%$ of the protein in cell extracts. Fractionation of the clarified cell extract prepared from cells grown in copper-supplemented medium by Sephadex G-75 gel filtration yielded a single copper-containing component, making up $4 \cdot 2 \%$ of total starting protein. After further fractionation of the eluent by ultrafiltration, the copper-containing fraction was chromatographed using a reverse-phase HPLC $\mu$ Bondapak $\mathrm{C}_{18}$ column to obtain a pure sample of the copper-binding component. Assuming no copper release from protein during purification, the copper-binding component was purified 210 -fold relative to whole-cell extract. Release of free copper ions could occur as a consequence of oxidation of the copper-binding protein. This final fraction contained $7 \cdot 2 \%$ of total copper and $0.03 \%$ of total protein. Only one copper-containing component was detected during the purification steps.

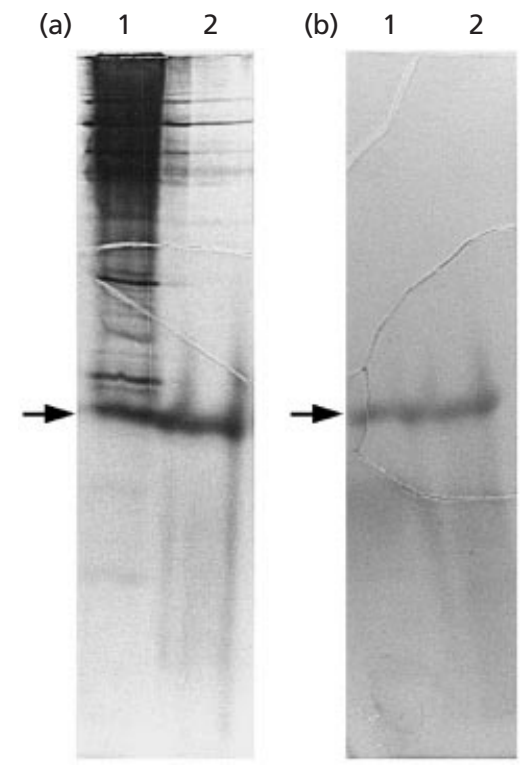

Fig. 1. Nondenaturing PAGE of the copper-binding protein from C. albicans. Upon completion of electrophoresis, the gel was cut into two strips longitudinally. One strip was used for protein staining with CBB R-250 (a), and the other was used for copper staining with SDTC. Lanes: 1, cell extract $(500 \mu \mathrm{g}) ; 2$, purified copper-binding protein $(1 \mu \mathrm{g})$.

Native-PAGE analysis of the purified component indicated the presence of a single band when stained with CBB and SDTC (Fig. 1). The molecular mass of the purified molecule was determined by HPLC gel filtration to be approximately $10000 \mathrm{Da}$.

\section{Preparation of apoprotein and amino-terminal sequence analysis}

To ascertain the nature of this copper-binding protein, further fractionation of the apoprotein prepared by guanidinium hydrochloride treatment was carried out using HPLC on a KW-802.5 column. The removal of copper ions from the protein is commonly accomplished by the proton displacement method (Nielson et al., 1985). This procedure was not effective with our protein, as it was found to precipitate upon acidification. Instead, copper removal was accomplished by boiling in a solution of $0 \cdot 1 \mathrm{M}$ EDTA in $6 \mathrm{M}$ guanidinium hydro-

Table 1. Summary of the purification of the copper-binding protein from C. albicans

\begin{tabular}{|c|c|c|c|c|c|c|}
\hline \multirow[t]{2}{*}{ Step } & \multirow{2}{*}{$\begin{array}{l}\text { Total protein } \\
\qquad(\mathbf{m g})\end{array}$} & \multirow{2}{*}{$\begin{array}{l}\text { Total Cu } \\
\quad(\mu \mathrm{g})\end{array}$} & \multirow{2}{*}{$\begin{array}{c}\mathrm{Cu} / \text { protein } \\
\left(\mu \mathrm{g} \mathrm{mg}^{-1}\right)\end{array}$} & \multicolumn{2}{|c|}{ Recovery (\%) } & \multirow{2}{*}{$\begin{array}{l}\text { Purification } \\
\text { (-fold) }\end{array}$} \\
\hline & & & & Copper & Protein & \\
\hline Cell extract & 231 & 4708 & 20 & 100 & 100 & 1 \\
\hline Sephadex G-75 & $9 \cdot 8$ & 2036 & 208 & $43 \cdot 2$ & $4 \cdot 2$ & 10 \\
\hline Ultrafiltration & $3 \cdot 2$ & 1135 & 355 & $24 \cdot 1$ & $1 \cdot 4$ & 18 \\
\hline Reverse-phase HPLC & $0 \cdot 08$ & 337 & 4212 & $7 \cdot 2$ & $0 \cdot 03$ & 210 \\
\hline
\end{tabular}




\begin{tabular}{|c|c|c|c|c|c|}
\hline & 1 & & & & 10 \\
\hline C. albicans & Ala- Ser-Gly- & Cys-Ser- & Cys & Gly-Ala- Asp- & Cys \\
\hline C. glabrata MT-1 & Met- Ala- Asn-Asp- & Cys Lys- & Cys & Pro- Asn-Gly - - & Cys \\
\hline N. crassa $\mathrm{Cu}-\mathrm{MT}$ & Met- - - Gly-Asp- & Cys Gly & Cys & Ser- Gly- Ala- Ser- Ser- & Cys \\
\hline Stone loach MT & Met- - - Asp- Pro- & Cys-Glu- & Cys & Ser- Lys- Thr- Gly-Thr- & Cys \\
\hline Mouse MT-1 & Met- Asp- Pro- Asn- & Cys Ser- & Cys & Ser- Thr- Gly- Gly- Ser- & $y s$ \\
\hline Equine MT-1B & Met- Asp- Pro- Asn- & Cys Ser- & Cys & Val-Ala- Gly- Glu- Ser- & Cys \\
\hline Human MT-2 & Met- Asp- Pro- Asn- & Cys Ser- & Cys & Ala- Ala- Gly- Asp- Ser- & ys \\
\hline
\end{tabular}

\begin{tabular}{|c|c|c|c|c|c|c|c|}
\hline & & & & 20 & & & \\
\hline C. albicans & Cys. & Ala-Ser- Glu- & Thr-Glu- Cy & Lys-Cys- & Ala- & - Ser- Lys- & \\
\hline C. glabrata MT-1 & Cys. & Pro-Asn Cys. & Ala- Asn- Gly & Gly Cys & Gln- & Cys Gl & \\
\hline N. crassa $\mathrm{Cu}-\mathrm{MT}$ & Cys & Gly-Ser- Gly- & Cys Ser- Cys. & Ser- Asn- & Cys- & Gly- Ser- & \\
\hline Stone loach MT & Cys & Gly-Ala-Thr- & Cys Lys- Cys & Thr- Asn- & -Cys- & Gln-Cys- & \\
\hline Mouse MT-1 & Cys & Thr- Ser- Ser- & Cys Ala-Cys & Lys- Asn- & Cys & ys- Cys- & \\
\hline Equine MT-1B & Cys & Ala- Gly- Ser- & Cys Lys-Cys & Lys- Gln- & - Cys- & Arg-Cys- & \\
\hline Human MT-2 & Cys & Ala- Gly- Ser- & Cys-Lys-Cys & Lys- Glu- & Cys & Lys- Cys- & \\
\hline
\end{tabular}

Fig. 2. Comparison of sequences of the $C$. albicans copper-binding protein and metallothioneins from C. glabrata (Mehra et al., 1989), Neurospora crassa (Lerch, 1980), stone loach (Kille et al., 1991), mouse (Glanville et al., 1981), horse (Kojima et al., 1976) and human (Karin \& Richards, 1982). Only the amino-terminal portions of the metallothioneins displaying sequence homology to the C. albicans copper-binding protein are shown. Cysteine residues are indicated by boxes. chloride containing $0 \cdot 1 \mathrm{M}$ Tris ( $\mathrm{pH} 8 \cdot 6$ ), using techniques described by Mehra et al. (1988). Fractions encompassing the copper-free protein peak were pooled and the sequence of the amino-terminal 24 residues was determined by Edman degradation (Fig. 2). The aminoterminal 24 residues of the polypeptide contained three repeating sequences of Cys-Xaa-Cys (Xaa refers to an unspecified residue), the Cys-Xaa-Cys motif being typical of MT. Furthermore, the first four cysteine residues of the C. albicans copper-binding protein occupied exactly the same positions as the first four cysteine residues in the amino-terminal sequence region of MTs characterized in other organisms (Fig. 2). In addition, serine residue 5 and lysine residue 19 were invariant with three vertebrate MTs. Note the complete lack of aromatic amino acids in the copper-binding protein from C. albicans as well as in all the MTs sequenced so far (Lerch, 1980; Mehra et al., 1988, 1989). Because of these common structural features, we categorize the $C$. albicans copper-binding protein as a member of the MT superfamily.

\section{The stoichiometry of copper binding determined by reconstitution of the apoprotein with $\mathrm{Cu}(\mathrm{I})$}

The copper-binding protein exhibited electronic transition in the near-UV similar to the typical chargetransfer transitions seen in copper-binding MTs (Fig. $3 a)$. The copper-binding protein was luminescent with an uncorrected emission maximum of $530 \mathrm{~nm}$ (Fig. 3b) when excited with UV light (from 300 to $370 \mathrm{~nm}$ ). The luminescence is characteristic of $\mathrm{Cu}(\mathrm{I})$-thiolate coordination in an environment shielded from solvent interactions (Mehra et al., 1988). Cu(I)-thiolate electronic transitions are salient features of copper-binding MTs.

It is the presence of repeating Cys-Xaa-Cys sequences in vertebrate MTs that makes these proteins effective metal-binding molecules (Lerch, 1980). Because the C. albicans copper-binding protein described here con- tained three Cys-Xaa-Cys sequences within its aminoterminal 24 residues, it could be expected to show metalbinding characteristics similar to those of vertebrate MTs. The stoichiometry of metal binding was determined by reconstitution of the apoprotein with $\mathrm{Cu}(\mathrm{I})$. Titration of the apoprotein with increasing mole equivalents of $\mathrm{Cu}(\mathrm{I})$ resulted in increased absorbance at $250 \mathrm{~nm}$ until $14 \mathrm{~mol}$ eq. copper had been added (Fig. 4). No further increase in absorbance occurred when up to 20 mol eq. of $\mathrm{Cu}(\mathrm{I})$ were added. The equivalence point of titration of the apoprotein with $\mathrm{Cu}(\mathrm{I})$ may be defined as the minimum number of mole equivalents of $\mathrm{Cu}(\mathrm{I})$ required to disrupt the metal-thiolate clusters. Proton displacement studies have shown that the $\mathrm{pH}$ at which $50 \%$ of bound $\mathrm{Cu}(\mathrm{I})$ ions dissociate from rat and probably other mammalian MTs is $2 \cdot 7$ (Nielson et al., 1985). The $\mathrm{pH}$ of half-dissociation of $\mathrm{Cu}(\mathrm{I})$ binding to $S$. cerevisiae MT and C. glabrata MT-II is $0 \cdot 3$ and $0 \cdot 8$, respectively (Byrd et al., 1988; Mehra et al., 1989). In this study, the C. albicans copper-binding protein lost $50 \%$ of $\mathrm{Cu}(\mathrm{I})$, as determined by loss of absorption at $250 \mathrm{~nm}$, at pH 1.6 (Fig. 5). Since the absorbance in the near-UV is dominated by sulfur $\rightarrow$ metal change transfer transitions (Nielson et al., 1985), the $\mathrm{pH}$-dependent loss of absorbance is a reflection of the dissociation of $\mathrm{Cu}(\mathrm{I})$.

\section{DISCUSSION}

This is the first report of the isolation of a copperbinding protein from $C$. albicans. It is known that clinical isolates of C. albicans and C. glabrata exhibit elevated resistance to copper salts (Butt \& Ecker, 1987). These species have been analysed for the induction of MT-like proteins in response to copper, cadmium, zinc and gold (Butt et al., 1984). Neither fungus produced a low-molecular-mass cysteine-rich protein in response to these metals. C. albicans strain 792 produced a protein similar to the MT found in S. cerevisiae in response to copper, and in C. glabrata strain 62 a unique, approximately 4500 Da protein was induced by copper (Mehra et al., 1988, 1989, 1990). In this study, C. albicans 

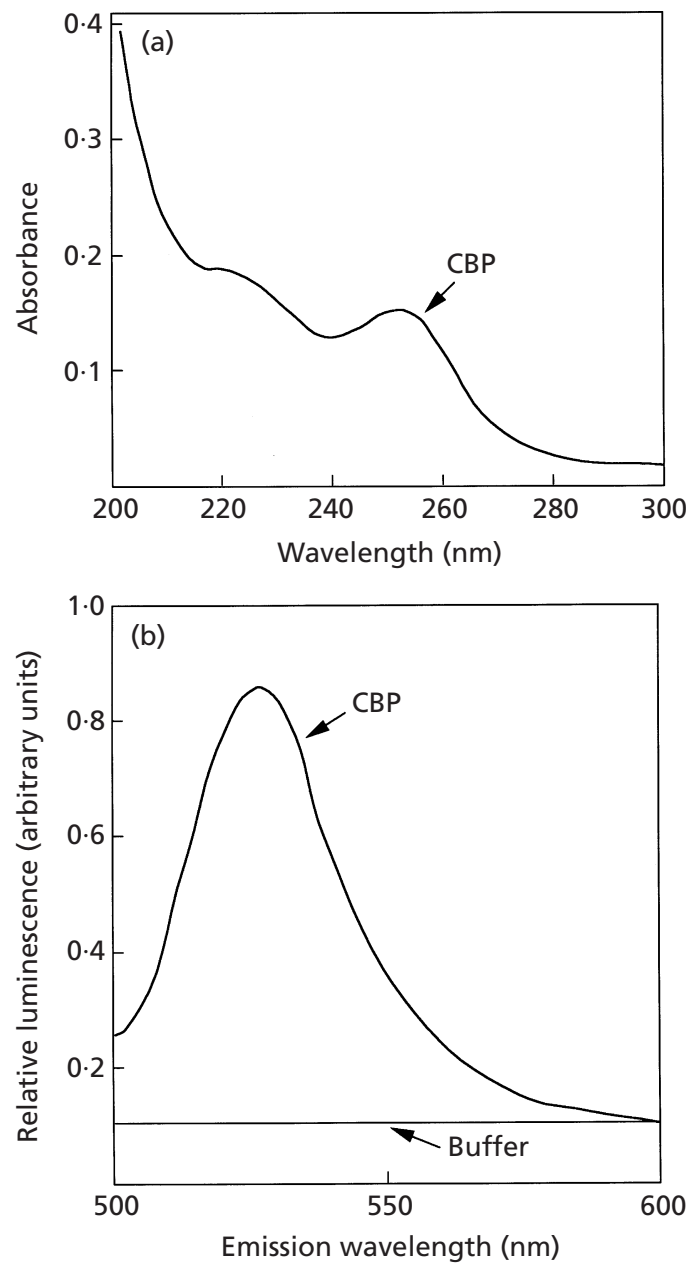

Fig. 3. UV absorption spectrum (a) and luminescence emission spectrum (b) of the $C$. albicans copper-binding protein. Each spectrum was recorded in $10 \mathrm{mM}$ Tris/ $\mathrm{HCl}$ buffer containing $0.2 \%$ mercaptoethanol $(\mathrm{pH} 7 \cdot 4)$.

KULM83-0300 cells cultured in the presence of $5 \mathrm{mM}$ $\mathrm{CuSO}_{4}$ synthesized a copper-binding protein. Only one copper-containing component was detected during the purification steps. The purified molecule had a polypeptide molecular mass of $10000 \mathrm{Da}$, as determined by HPLC gel filtration.

MTs have been described in most vertebrate and invertebrate species as low-molecular-mass proteins with high cysteine content (approx. 30\%), a lack of aromatic residues and the presence of 7-12 heavy metal atoms per molecule (Kagi, 1993). Vertebrate MTs constitute a family of highly conserved proteins and the positions of the cysteine residues involved in metal binding are invariant (Hamer, 1986; Kagi \& Kojima, 1988). Isometallothioneins from the invertebrate Scylla serrata show significant homology to each other as well as to vertebrate MTs (Hamer, 1986; Kagi \& Kojima, 1988). In contrast, the two MT genes in the invertebrate Drosophila and C. glabrata encode proteins which show little sequence homology to each other (Lastowski-Perry

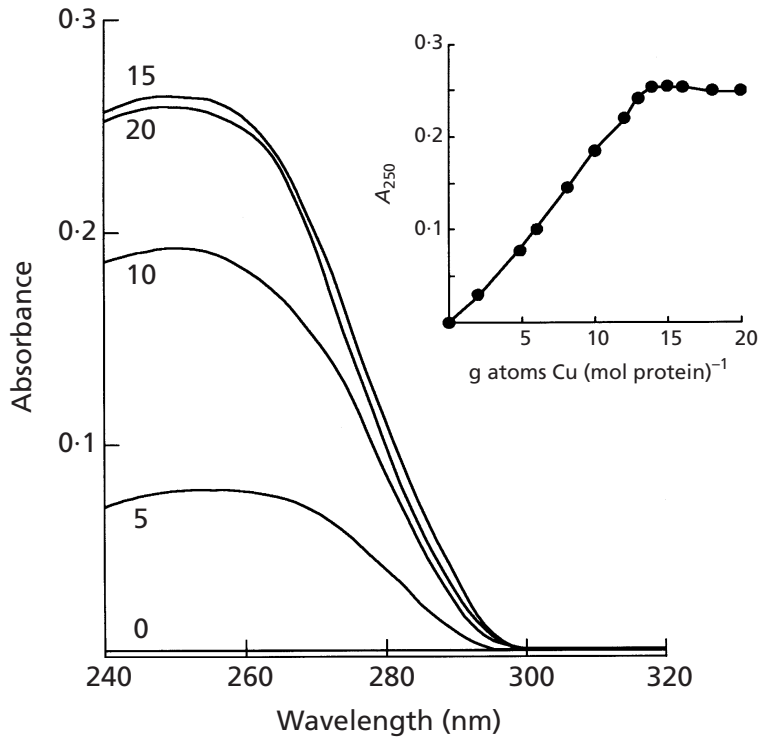

Fig. 4. UV absorption spectra of apoprotein reconstituted with 0-20 copper ions per molecule. The curves of increasing absorbance represent $0-20 \mathrm{~mol}$ eq. of $\mathrm{Cu}(\mathrm{l})$ as indicated by the numbers adjacent to the curves. Apoprotein $(4 \mathrm{nmol})$ was titrated with 1-20 mol eq. of $\mathrm{Cu}(\mathrm{I})$ as described in Methods. The inset shows the absorbance at $250 \mathrm{~nm}$ as a function of added $\mathrm{Cu}(\mathrm{I})$.

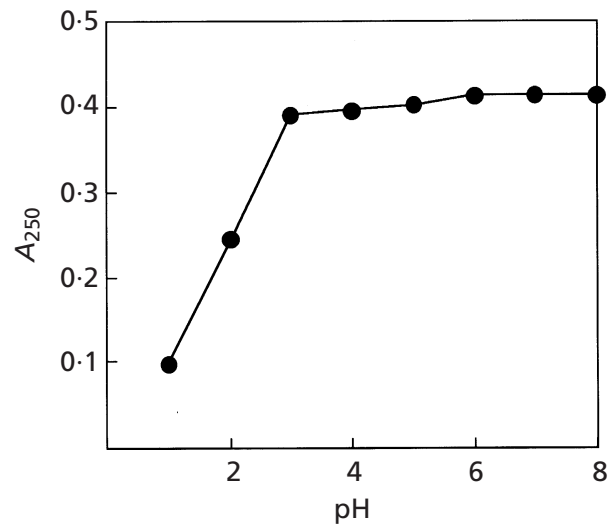

Fig. 5. $\mathrm{pH}$ titration of the $C$. albicans copper-binding protein. Samples of the native protein $(4 \mathrm{nmol})$ were adjusted to the desired $\mathrm{pH}$ as described and the absorbance of each sample was then recorded at $250 \mathrm{~nm}$.

et al., 1985; Mehra et al., 1989). In this study, the C. albicans copper-binding protein exhibited the typical MT sequence motif, Cys-Xaa-Cys. The role played by these sequence motifs in the formation of metal clusters in MTs is well recognized (Hamer, 1986; Kagi \& Kojima, 1988). Thus the C. albicans copper-binding protein is structurally analogous to other well-characterized MTs.

In many cells, MT appears to exist with varying ratios of bound copper. Our reconstitution study suggested that 
the equivalent extent of $\mathrm{Cu}(\mathrm{I})$ binding of the purified C. albicans apoprotein was approximately $14 \mathrm{~mol}$ eq. Concentrations of copper in excess of 14 ions per molecule did not alter the absorption properties of the molecule. These results suggested that binding was specific. It is stressed that the value of $14 \mathrm{~mol} \mathrm{eq}$. is not rigorous since the UV absorption method provides only an approximation. Substantiation of these results could be obtained using luminescence (Mehra et al., 1989). Mammalian MT usually binds seven zinc ions, but it also can contain copper, cadmium and traces of other metals. Although binding stoichiometries and coordination geometry have not been clearly established for metal ions, $\mathrm{Cu}-\mathrm{MT}$ is one form of the protein that deviates from the usual coordination of seven tetrahedrally bound metal ions per polypeptide (Boulanger $e t$ al., 1983; Nielson \& Winge, 1983). Nielson et al. (1985) found that 11 or 12 copper ions were bound to MT. The S. cerevisiae CRS5 MT-like protein (Culotta et al., 1994; Jensen et al., 1996) and C.glabrata MT (I and II) (Mehra et al., 1989) bind in excess of 10 copper ions per molecule. It is important to understand the coordination properties and structure of $\mathrm{Cu}-\mathrm{MT}$ because the protein may function in cellular processes involving copper (Aschner, 1996; Jasani \& Schmid, 1997). Further studies to elucidate the gene sequence and the cluster structure of the $\mathrm{Cu}$-protein are in progress.

\section{REFERENCES}

Aschner, M. (1996). The functional significance of brain metallothioneins. FASEB J 10, 1129-1136.

Berger, B., Dallinger, R., Gehrig, P. \& Hunziker, P. E. (1997). Primary structure of a copper-binding metallothionein from mantle tissue of the terrestrial gastropod Helix pomatia L. Biochem J 328, 219-224.

Boulanger, Y., Goodman, C. M., Forte, C. P., Fesik, S. W. \& Armitage, I. M. (1983). Model for mammalian metallothionein structure. Proc Natl Acad Sci USA 80, 1501-1505.

Bradford, M. M. (1976). A rapid and sensitive method for the quantitation of microgram quantities of protein utilizing the principle of protein-dye binding. Anal Biochem 72, 248-254.

Butt, T. R. \& Ecker, D. J. (1987). Yeast metallothionein and applications in biotechnology. Microbiol Rev 51, 351-364.

Butt, T. R., Sternberg, E. J., Gorman, J. A., Clark, P., Hamer, D., Rosenberg, M. \& Crooke, S. T. (1984). Copper metallothionein of yeast, structure of the gene, and regulation of expression. Proc Natl Acad Sci USA 81, 3332-3336.

Byrd, J., Berger, R. M., McMillin, D. R., Wright, C. F., Hamer, D. \& Winge, D. R. (1988). Characterization of the copper-thiolate cluster in yeast metallothionein and two truncated mutants. J Biol Chem 263, 6688-6694.

Cervantes, C. \& Gutierrez-Corona, F. (1994). Copper resistance mechanisms in bacteria and fungi. FEMS Microbiol Rev 14, 121-138.

Culotta, V. C., Howard, W. R. \& Liu, X. F. (1994). CRS5 encodes a metallothionein-like protein in Saccharomyces cerevisiae. J Biol Chem 269, 25295-25302.

Fischer, E. H. \& Davie, E. W. (1998). Recent excitement regarding metallothionein. Proc Natl Acad Sci USA 95, 3333-3334.

Glanville, N., Durnam, D. M. \& Palmiter, R. D. (1981). Structure of mouse metallothionein-1 gene and its mRNA. Nature 292, 267-269.

Hamer, D. H. (1986). Metallothionein. Annu Rev Biochem 55, 913-951.

Jasani, B. \& Schmid, K. W. (1997). Significance of metallothionein overexpression in human tumours. Histopathology 31, 211-214.

Jensen, L. T., Howard, W. R., Strain, J. J., Winge, D. R. \& Culotta, V. C. (1996). Enhanced effectiveness of copper ion buffering by CUP1 metallothionein compared with CRS5 metallothionein in Saccharomyces cerevisiae. J Biol Chem 271, 18514-18519.

Kagi, J. H. R. (1991). Overview of metallothionein. Metallobiochemistry part B. Metallothionein and related molecules. Methods Enzymol 205, 613-626.

Kagi, J. H. R. \& Kojima, A. Y. (1988). Metallothionein II. Basel: Birkhauser.

Karin, M. \& Richards, R. I. (1982). Human metallothionein genes - primary structure of the metallothionein-II gene and a related processed gene. Nature 299, 797-802.

Kille, P., Stephens, P. E. \& Kay, J. (1991). Elucidation of cDNA sequences for metallothioneins from rainbow trout, stone loach and pike liver using the polymerase chain reaction. Biochim Biophys Acta 1089, 407-410.

Kojima, Y., Berger, C., Vallee, B. L. J. \& Kagi, H. R. (1976). Amino acid sequence of equine renal metallothionein-1B. Proc Natl Acad Sci USA 73, 3413-3417.

Lastowski-Perry, D., Otto, E. \& Maroni, G. (1985). Nucleotide sequence and expression of a Drosophila metallothionein. J Biol Chem 260, 1527-1530.

Lerch, K. (1980). Copper metallothionein, a copper-binding protein from Neurospora crassa. Nature 284, 368-370.

Lippert, B. (1992). From cisplatin to artificial nucleases. The role of metal ion-nucleic acid interactions in biology. Biometals $\mathbf{5}$, 195-208.

Liu, X. D. \& Thiele, D. J. (1997). Yeast metallothionein gene expression in response to metals and oxidative stress. Methods 11, 289-299.

Madhani, H. D. \& Fink, G. R. (1998). The control of filamentous differentiation and virulence in fungi. Trends Cell Biol 8, 348-353.

Malavasic, M. J. \& Cihlar, R. L. (1992). Growth response of several Candida albicans strains to inhibitory concentrations of heavy metals. J Med Vet Mycol 30, 421-432.

Maret, W. \& Valle, B. L. (1998). Thiolate ligands in metallothionein confer redox activity on zinc clusters. Proc Natl Acad Sci USA 95, 3478-3482.

Mehra, R. K. \& Winge, D. R. (1988). Cu(I) binding to the Schizosaccharomyces pombe $\gamma$-glutamyl peptides varying in chain lengths. Arch Biochem Biophys 265, 381-389.

Mehra, R. K. \& Winge, D. R. (1991). Metal ion resistance in fungi: molecular mechanisms and their regulated expression. $J$ Cell Biochem 45, 30-40.

Mehra, R. K., Tarbet, E. B., Gray, W. R. \& Winge, D. R. (1988). Metal specific synthesis of two metallothioneins and $\gamma$-glutamyl peptides in Candida glabrata. Proc Natl Acad Sci USA 85, 8815-8819.

Mehra, R. K., Garey, J. R., Butt, T. R., Gray, W. R. \& Winge, D. R. (1989). Candida glabrata metallothioneins. Cloning and sequence of the genes and characterization of proteins. J Biol Chem 264, 19747-19753.

Mehra, R. K., Garey, J. R. \& Winge, D. R. (1990). Selective and tandem amplification of a member of the metallothionein gene family in Candida glabrata. J Biol Chem 265, 6369-6375. 
Naiki, N. \& Yamagata, S. (1976). Isolation and some properties of copper-binding proteins bound in a copper-resistant strain of yeast. Plant Cell Physiol 17, 1281-1295.

Nielson, K. B. \& Winge, D. R. (1983). Order of metal binding in metallothionein. J Biol Chem 258, 13063-13069.

Nielson, K. B., Atkin, C. L. \& Winge, D. R. (1985). Distinct metalbinding configurations in metallothionein. J Biol Chem 260, 5342-5350.

Palmiter, R. D. (1998). The elusive function of metallothioneins. Proc Natl Acad Sci USA 95, 8428-8430.

Simpson, J. A., Cheeseman, K. H., Smith, S. E. \& Dean, R. T. (1988). Free-radical generation by copper ions and hydrogen peroxide. Biochem J 254, 519-523.

White, C., Sharman, A. K. \& Gadd, G. M. (1998). An integrated microbial process for the bioremediation of soil contaminated with toxic metals. Nature Biotechnol 16, 572-575.

Winge, D. R. (1998). Copper-regulatory domain involved in gene expression. Prog Nucleic Acid Res Mol Biol 58, 165-195.

Winge, D. R., Nielson, K. B., Gray, W. R. \& Hamer, D. H. (1985). Yeast metallothionein. Sequence and metal-binding properties. J Biol Chem 260, 14464-14470.

Zhu, Z. \& Thiele, D. J. (1996). A specialized nucleosome modulates transcription factor access to a C. glabrata metal response promotor. Cell 87, 459-470.

Received 30 September 1998; revised 26 April 1999; accepted 17 May 1999. 